Vol.3, No. 3, September 2021, pp. 106-118, doi.org:10.52567/pjsr.v3i3.231

www.pjsr.com.pk

\title{
SOCIAL VULNERABILITY OF COASTAL COMMUNITY DUE TO CLIMATE CHANGE: AN EXPLORATORY STUDY OF COASTAL REGION OF SINDH
}

\author{
Tahir Iqbal \\ Ph.D. scholar, Department of Sociology, \\ University of Sindh, Jamshoro \\ tahirei@gmai.com \\ Dr Ameer Ali Abro \\ Associate Professor, Department of Sociology, \\ University of Sindh, Jamshoro \\ ameeraliabro@usindh.edu.pk
}

\begin{abstract}
Climate change is neither an overnight phenomenon nor does it spans on days and months. It is a gradual process that takes years to makes coastal communities socially vulnerable. Social vulnerability is the susceptibility of individuals to the natural disasters. It has been witnessed that global coastal communities have social vulnerability due to climate change. Similarly, the coastal community of Sindh is also linked to social vulnerability due to climate change. The current study intends to explore the social vulnerability of fishermen of coastal communities due to climate change. The qualitative research is widely accepted to find out the social vulnerability. The research population of this study is fishermen living in the Thatta, Sujawal, and Badin districts of Sindh province, Pakistan, selected through the purposive sampling. In each district, 10 IDIs ((In-depth Interview) and 3 FGDs (Focus Group Discussion) were conducted with fishermen after building rapport among them. The sample size included 30 IDIs and 9 FGDs in the study. The study revealed that climate change (cyclone, flood, etc.) and decrease in freshwater lakes have a tremendous effect in lowering fishermen socioeconomic status; reducing their livelihood resources, low income, and poor health of fishermen. Moreover, the increases in expenditure to sail for fishing, and the exploitation by middlemen have also been noticed by this study.
\end{abstract}

Keywords: Social Vulnerability, Climate Change, Fishermen, Coastal Region, Sindh,

\section{INTRODUCTION}

It has been found by researches that coastal community is susceptible due to climate change (Salik, et al, 2015). Sea rise has been constantly threatening to the community (Oliver-Smith, 2009). In the social and physical world, differential ability of individuals or communities to face natural hazards is called social vulnerability (Ekanem \& Umoh, 2021). Moreover, social vulnerability stems from minimum coping capacity and a high level of susceptibility. The social vulnerability has been often accessed on the intensity of susceptibility. To cope with a natural disaster is also a part of the social vulnerability and it has received little attention by researchers (Chakraborty et al., 2020). The coping mechanism includes the use of accessible resources of either to group or to an individual to diffuse the effect of calamity (Drakes, et al, 2021).

The twenty-first century has witnessed climate change as a major challenge to life, wellbeing, livelihood and health of human beings (Adger, 2006). The global community has noticed global warming and climate change as significant social issues (Kelly \& Adger, 2000). Environmental change has challenged the survival of human beings (Dolan \& Walker, 2003; Omerkhi et al., 2020). International and national communities have been kept involved to address climate change threats. Efforts have been made to recognize that climate change is a reality (Fussel, 2007), and it cast bad impacts on the economic and 
social life of coastal communities mainly, and others generally (Felsenstein \& Lichter, 2014). It has also disturbed the ecosystem, and the lives of the global community are at risk (Pakistan, 2016).

In the views of Lockie (2015), in developing countries, the livelihood of population is consequently being jeopardized by changes in the environment and climate variations (Chaudhry, 2017). The people are facing social vulnerability issues. There is the probability that natural hazards like cyclones or floods are closely linked with the unavailability of fresh water, salinity, and have impacts on fishing in sea areas. There are evidences of the US denial about severe impact of climate change around the globe (Collomb, 2014). Keeping this in view, environmental sociologists are trying for the mitigation of climate change and are making efforts to minimize the impact of climate change on the society. They are also proving that climate change is a global issue (Elliott, 2018). Similarly, in Pakistan, climate change is a grave concern of people. Climate change has been affecting marine fishing agricultural sectors in the coastal region of Sindh for a long time. The current study is to look into climate change effects on the coastal community of Sindh.

\section{PROBLEM STATEMENT}

The coastal belt of Sindh province is the most vulnerable area to disasters. Most of the fishing community resides there, and these disasters increase their poverty and decrease their ability to give maximum productions (Khan, 2001; Salik et al, 2015). The social vulnerability includes susceptibility to livelihood, and the vulnerability of children, elderly people, women, and disabled people in the region (Mahessar et al, 2019). Sometimes, the socially vulnerable community is forced to migrate (Kayani, 2017). One of the key survival strategies of households in times of crisis is the sale of personal assets (Hunter, 2006), often those belonging to women, such as livestock, jewellery, utensils, and household goods (Razzaq et al, 2012).

\section{RESEARCH QUESTION}

What are the social vulnerabilities of the coastal community (Fishermen) of Sindh due to climate change?

\section{RESEARCH OBJECTIVE}

To explore the social vulnerability of the coastal community of Sindh due to climate change.

\section{SIGNIFICANCE OF STUDY}

The current study is very significant because it is a grave issue that cannot be ignored at any cost. The UNO, Intergovernmental Panels on Climate Change (IPCC), and other organizations are taking serious interest to minimize the effect of climate change. The current study has highlighted the miseries and issues related to social vulnerability due to climate change of the community of the coastal region. This study is also helpful to design policy for the coastal community who are engaged in the fishing profession.

\section{LITERATURE REVIEW}

Natural hazards and procedure of mitigating climate change to reduce any kind of disaster functions to measure exposure to hazard and its' sensitivity to hazard and how to physically respond it. In this perspective, the social landscape is regarded as static and seems like an external factor that is not part of the situation (Martins \& Gasalla, 2020). Contrastingly, it is openly believed that exposure, sensitivity, and adaptation ability are dynamic and different regarding time and communities. However, social vulnerability is associated with social and economic dimensions by reviewing past with reference to present situations of masses to understand vulnerabilities (Waly et al., 2021).

Wisner (2004) says that social vulnerability is the condition that affects individuals' ability to predict, cope with, shows the difference with, or recuperate from the effects of hazards (Berke et al., 2019). Moreover, livelihood and social vulnerability are linked with each other (Alhassan, 2019). Social vulnerability demonstrates exposure of individual or community to stress in consequence to 
Iqbal \& Abro

environmental and social changes (Cutter et al., 2009). Here, stress means unpredicted change or disturbance to livelihood (Adger, 1999).

For Kelly and Adger (2000), the individual and social group's capacity in dealing, coping and adaptation to threat is pivotal for well being and livelihood of fishermen, by stressing on socio-economic and organizational restraints that reduce the capacity to respond efficiently (McCarthy et al; 2001; Conner, 2005; Torresan et al., 2012; Singh et al., 2014; Burton et al., 2018). The another aspect of social vulnerability is the tendency of damage caused by natural disaster (climate change) to a person's mental or physical health, which may affect at a collective level i.e., education, health services, and livelihood along with a social system that possesses characteristic of gender, discrimination, social status (Guths, et al, 2017) and economic conditions (Birkmann et al., 2013).

Katic (2017) has studied numerous operational definitions of social vulnerability to natural hazards, but the most common is defined as the differential capacity of groups and individuals to deal with hazards (Nicholls et al., 2008) based on their positions within physical and social worlds (Mavhura et al., 2017), or as the inability to take effective measures against losses (Clare \& Weninger, 2010). Mohapatra and Upadhyaya (2020) have found some factors that enhance or reduce the social vulnerability of coastal people. These includes social factors, economic factors, demographic factors, education and technology. The social factors either enhances or reduces social vulnerability. Truly, the higher the social status a person possesses, the more resources are available for him (Mayfield-Johnson, et al, 2020). As a result, there is more resilience of the person against disasters or incidents. For example, in India, the less privileged communities have inadequate resilience and find themselves very vulnerable to a natural disaster (Pallewatta, 2010).

The social factors also include the individuals who are dependents on others like women, aged people, children, and special people (Guths et al., 2017). Economic conditions of the individual of the coastal community also affects their social vulnerability (Arkema et alm., 2013). The research reveals that individuals having better economic positions can cope with any kind of natural hazard easily for a long time (Adger, 2006).

The population size of the community also matters in determining social vulnerability. A dense population contributes more to vulnerability because the members of the community have to share the same resources and their quality of life get affected. The age of family members also matters in social vulnerability as the family who has more young ones and fewer children, their tendency to social vulnerability is reduced, and if a family has more children; they are more exposed to social vulnerability. The movement of children is restricted and their dependency increases during hazards (Collins, et al, 2013). They are entirely dependent on their parents or on adult members. In this way, their dependency increases their social vulnerability (Mayfield-Johnson, et al, 2020).

The scholars are of the view that educated communities are more resilient to natural hazards than those who are illiterate or with little education. With the help of education, they can tailor their lifestyles according to the nature of hazards. Moreover, education provides another opportunity for livelihood. In this way, their social vulnerability is reduced (Clare \& Weninger, 2010, Tapsel et al., 2010).

Asugeni et al., (2015) have conducted a cross-sectional study on the mental health of coastal communities of Solomon Islands. The study reveals that the community members find them more vulnerable when they there is rise in sea level and sometimes, the seawater enters their houses. In this way, their household items got damaged (Elrick, et al, 2015). Afterwards, they try to settle at high places where seawater cannot enter. Leaving their houses and get settled somewhere else is not easy for them because they feel if they move away, they will have a weak tribal affiliation (Asugeni et al., 2015). Mixing seawater with drinking water also adds to their miseries. They expect government assistance to reduce their vulnerability, but some of them are aware of the limitations of their government. The government machinery cannot fully help the coastal community, who are in the remote areas and have unpaved and uneven roads. In addition to that, social disorganization also exists because of climate change, and the community needs counselling to maintain the organization in community (Singh, et al, 2014). 
To understand the social vulnerability of elderly people, Guths et al., (2017) conducted a crosssectional study on the north coastal region of Rio Grande does Sul, Brazil. The study reveals that elder people of coastal regions find their health vulnerable due to climate change. The succumbed to more chronic diseases due to climate change, and they are now more dependent on their family members.

The descriptive study of Hunter (2006) in the coastal region of Ghana highlights the social vulnerability of men along with women due to climate change (Alhassan et al., 2019). According to the findings of the study, the community is forced to drink contaminated water, which contributes to the health issues of the livelihood of the local community (Pallewatta, 2010). Moreover, climate change has increased the burden of women in doing household chores (Sultana, 2010). The women have to fetch drinking water from remote areas.

A study was conducted by Glavovic and Boonzaier (2007) on the social vulnerability of the community due to climate change in the Maputaland region of KwaZulu-Natal, South Africa. The study reveals that the community faces poverty and unemployment due to climate change which is affecting their livelihood (Berman et al., 2020) and they do not have any alternatives (Kayani, 2017). They even do not have any support from the civil organizations to address their social vulnerability. The development in the coastal region is going on, but the community does not have access to the fruits of development.

Participatory research was carried out by Bunce et al., (2010) in the marginal African coasts. The study shows that climate change influences fishing business in the coastal region. Moreover, climate change and dam constructions also enhanced the social vulnerability of the fishing and agricultural communities.

The balance between the river and marine fishing at Macaneta could not be maintained due to climate change. Consequently, there is a shortage of food and spread of diseases that affected human beings, livestock and crops. The fodder for livestock started reducing, which escalates fishermen miseries and worries (Asugeni et al., 2015).

Another research was conducted by Kulkarni et al., (2016) on the school children of the coastal region of Karnataka, India. The study has found that many children are underweight and they are also suffering from dental caries due to poor socio-economic status of their families and climate change. Climate change has severely affected their livelihood in the coastal area (Conner, 2005).

The case study research of Shameem et al., (2014) in the southwest coastal region of Bangladesh reveals that climate change has increased the salinity in the soil and reduced the drinking water resources for the community. It also affects the production of crops in the region, and the shrimp aquaculture has also been affected. In other words, shrimp farming is reducing day by day.

The study of Uddin et al., (2019) in the Bangladesh coastal region highlights the vulnerability of community related to the economic condition, agriculture, water, health, and infrastructure. Samarakoon (2004) has also found that climate change along with poor management has badly influenced the livelihood of fishermen in the region. Similarly, Cahaya et al., (2019) asserted that the Indonesian fishermen of the coastal region also appeared to be affected due to climate change. It is has become difficult for them to meet the basic needs of their families.

In Pakistan, the research has shown that the coastal area of Sindh is becoming highly vulnerable to disasters due to rapid climate changes (Farooqi et al., 2005; Kayani, 2017; Mahessar et al., 2019), and the areas have seen sea level rise, sea intrusion and soil erosion (Nicholls et al., 2008). Reports have shown that the area is highly socially vulnerable and also severely influenced by the climatic catastrophes (Jamali et al., 2011; Chaudhry, 2017). For example, climate change has destroyed biological diversity in the coastal region (Qureshi, 2011). The coastal districts of Thatta, Sujawal, and Badin are positioned on the Indus delta and are very vulnerable to disasters due to cyclone (Rasul et al., (2012), riverine floods, and flash floods (Ullah et al, 2018).

Within three years, these areas of the coastal belt have seen major floods in history. Moreover, there is no supportive infrastructure in remote areas of these districts at the coast side (Asugeni et al., 2015). This area is placed in the lowest position in terms of the Human Development Index in Pakistan (Khawaja et al., 2014). In case of an emergency, like a cyclone or flash flood, the coastal community is warned through verbally or Radio (Nawaz \& Naeem, 2016). In this way, receiving information or getting 
alarmed about any hazard got delayed and they suffered from big human and economic losses (Berke et al., 2019). The marginalization in terms of education and increase in fatalities due to poor livelihood increases their burden of vulnerability (Kayani, 2017). The poor infrastructure like roads would not resist before any disaster and as a result, they receive severe damages (Rasul et al., 2012, Khawaja et al., 2014).

A study conducted by Salik et al., (2015) in Keti Bander, Sindh, identified that the coastal community is very vulnerable due to climate change. The residents of Keti Bander do not have access to basic facilities; there are insufficient livelihood resources, poor income (Conner, 2005), and lower level of education facilities for children. All these problems contribute to their vulnerability and their miseries. But their family ties are strong that helps them connect in case of disaster; however, this relationship cannot respond effectively to the natural disaster because of poverty.

In the coastal belt of Sindh, Khushk and Lashari (2007) have found that the impoverished socioeconomic condition of farmers in the area is a hurdle to yield major crops. In these areas, during a disaster; the weak, poor, children, women, and minorities are found marginalized and face discrimination during the relief process. The food packets and shelter equipment are mainly handover to powerful people and the poor and weak failed to receive any relief (Khawaja et al., 2014).

\section{RESEARCH METHODOLOGY}

Qualitative research is suitable to explore the beliefs, concepts, and behaviours that are linked to this particular issue (Bengtsson, 2016). In the coastal region of Sindh, social vulnerability due to climate change can be better explored and understood by adopting qualitative research design, because it directs researchers to develop concepts about social vulnerability, which helps in understanding the social phenomena of climate change in natural settings. This kind of research also gives fair emphasis to the meaning, experience, and view of the participants. In qualitative research, IDI (In-depth interview), FGD (focus group discussion) and observation are research tools that are used to collect primary data.

In a climate change context, interview schedules, focus group discussions, and observation are used as research tools. The IDI demonstrates contextualized amount of people's trust as demonstrated in their languages. Moreover, it also provided the contradiction and dynamism that is found in the representation of the world by people (Meyappan et al., 2021). The FGD (guided by a set of questions) and interactive sessions with group members was enough for researcher to collect diversified opinions from participants (Turner, 2010).

The population of the study is fishermen, who are engaged in marine fishing communities; living in the coastal region of Thhatha, Sajawal, and Badin Districts of Sindh. Non-random sampling was employed that seeks conceptual applicability rather than quantitative representativeness. It also seeks to capture the range of views and experiences, pursue saturation of data and draw theory from data.

To develop new themes and concepts, Devers and Frankel (2000) are of the view that the purposive sampling is designed to deeply understand the stories and experiences of selected community members. In the present study, the sampling technique is purposive sampling for IDIs and FGDs. In each district, there were 10 IDIs and 3 FGDs with fishermen. The ages of fishermen range from 35-70 years, included boat crews and captains who have been in fishing business generation after generation. Volunteer services were taken from local people to select the right fishermen who have rich experience of fishing. It is pertinent to mention that the research instruments were translated into the Sindhi Language (Local language) for the coastal community. The research tools of IDI and FGD are based on constructs of climate change and social vulnerability, and societal impact of climate change on fishermen of the coastal community. These constructs have been derived from the extensive literature review. The discussion and talk of IDIs and FGDs were recorded where consent was given by respondents.

Thematic analysis technique was used to analyze collected data from IDIs and FGDs. Thematic analysis stands for the procedure to categorize verbal along with behavioural data to classify and summarize the data according to themes.

\section{RESULTS AND DISCUSSION}


Social Vulnerability of Coastal Community Due to Climate Change

Different scholars and experts of climate change believes that climate change is not an overnight phenomenon. It takes years to change. Similarity, due to climate change, sea intrusion and sea erosion are also gradual and spans over a long period. So the findings of the current study are limited to the climate change effect on fishermen's social vulnerability.

\section{Social Vulnerability Fishermen}

The social vulnerability of coastal communities includes the vulnerability of livelihood, their social status, health, and social vulnerability of their family as well. They are living a very painful and miserable life. In the coastal region, the fishermen are socially vulnerable due to climate change.

It was shared by a fisherman that 30-40 years ago, there were much more fish in the sea and some fishermen were involved in creeks fishing. One fisherman says, "Gradually, due to sea intrusion and sea erosion, now those creeks have become part of the sea, and new creeks have developed in the coastal region, and new islands have been developed. The fisher community is of the view that land has gradually become barren."

The fishermen are of the view that due to climate change; their fishing, their livelihood, social status, and health are exponentially at risk. They have very painful stories to reveal their vulnerability. All the fishermen unanimously say that 1998 cyclone A2 has badly affected their livelihood. In their words, "We used to catch fish a lot in the past, but now, many fishermen have changed their profession and adapted to other jobs because they think the income from catching fish cannot bear their family expenditure."

Freshwater lakes at coast areas are affected due to the entering of seawater that adds salt. Lakes are becoming parts of the sea. This is because of rise of the sea-level and sea intrusion. The old lakes are now filled with seawater and as a result; fishermen who used to catch fish in freshwater lakes are forced to do fishing in the sea. In the old lakes, there was fresh water, but now, the freshwater is turned into salty, and fish are less. Other fisherman reports, "Now fish lakes are reducing because seawater has entered the freshwater lakes. So freshwater fish is not available and people who dealt with this business have lost their livelihood."

\section{Cyclones and Social Vulnerability of Fishermen}

It was shared by some fishermen that in 2017, one boat sank and 7 fishermen disappeared. Some major and small level cyclones have casted a very drastic effect on the fishermen community. It was told that Cyclone in 1800, and Tsunami in 1901 displaced Shah Bander. Due to the tsunami and cyclone, Keti Bandar was repopulated and resettled three times at three different places. The first Keti Bandar and the second Keti Bandar are now in the sea.

The fisher community is of the view that 1998 cyclone A2 affected Badin, Jati, Shah Bander, Kharo Chan, and Katei Bender. The fishermen of Badina dn Jati are of the view that the 2007 cyclone Twister hit Jati and Badin. Moreover, the 2014 cyclone affected at small scale (35 KM to the shore).

During probing, one fisherman shared his grief by heartedly revealing, "Approximately 23 years ago, we had 36 boats and we also dealt in fish trading. In our Deh (village), the 1998 cyclone took the lives of 23 fishermen and everything from us. We lost everything to the cyclone." He further said, "Even the weather forecast department did not inform us timely. In our village, 300-400 houses were destroyed." In addition to it, he stated that he lost his one son and some immediate relatives in a cyclone. Due to the suffering, his one son suffered from psychologically issues, and one daughter also got mental health problems because of the depression and trauma of cyclone, cyclone still haunted them like a nightmare. Similarly, another fisherman reported that his village fellows also suffered due to cyclones. Another fisherman told, "In our village, nearly 50 boats got sunk in the sea and cyclones displaced 300400 families." 
Iqbal \& Abro

The other fisherman in an interview told his painful story. He has narrated that the 1998 cyclone devastated them as they lost 2-3 boats in the cyclone. The other said, he had 2 boats, but now he has 1 boat left. The other fisherman had lost 3 boats in a cyclone, and now work in other boats. He said that it is not easy to work for other boats while he also was the owner of the boats in the past.

In a group discussion, some fishermen unanimously said that they have left nothing; they lost their loved ones, their houses, lands, and boats in a cyclone. Now, they work as labourers and workers to move peddle of life. One fisherman told that he had two boats, and his maternal uncle had three boats, but cyclone sunk their boats in the sea and now they are labours at someone else boat, and also work at agricultural land of local landlord. Another fisherman told that in the past, they had big boats, but now have a small boat that has 3-4 fishermen crew. The Cyclone of 1998 destroyed their boats and it was not possible to buy new boats, and some of them are working as workers in other boats or boats owned by Seth (investor).

\section{Increase in fishing expenditure}

It was shared that as climate and weather are changing, it is colder and hotter than it was 30-40 years ago. According to a fisherman, "As far as increase in fishing expenditure is concerned, currently, 15-20 days sea trip is equal to 3 days sea trip in past." He further added, "There was a time when in 10-12 days trip of the sea, it used to cost Rs 50000 for fishing, but now expenses have been increased to 5-8 lacs, which is not affordable."

\section{Vulnerability of Boat Machinery}

Climate change has increased high tides in the sea. In the past, the high tides magnitude was not enough to damage their boats. Now, the high tides affect the boats which need maintenance and repairing. The fishermen repair their boast themselves. Now, a lot of effort and expenditure is required for fishing in the sea. Climate change has also increased the financial burden on fishing in the open sea. Fish is available in the open sea, while fishermen told that the engines of boats are out of order, and repairing of boats requires a lot of money which they do not have enough to buy parts of boats. So, they cannot afford to have open sea trips for fishing as repairing of boats takes their income; the price of spare parts is very high, they live from hand to mouth, and profit is less than expenditure.

\section{Vulnerability due to Indian Marine Security}

All fishermen are of the view that fear always persist to be caught by Indian marine security near the territory of Pakistan and India. Some fishermen of Badin shared that Indian marine security caught some Pakistani boats, two fishermen of boats escaped and fled to islands and hid in mangroves in the sea. Later when they felt the danger is over, they managed to escape. Another fisherman is of the view that their two boats were caught by Indian marine forces, the boats costed 50 lacs, and now his three sons are working as labourers at someone else boats. Pakistan Fishermen Forum documented accounts of fishermen who are caught by Indian marine security. It has been reported by fishermen that the prisoners are kept hungry and are provided insufficient food in Indian prisons. They are also tortured and brutally behaved by Indian prison staff, when India and Pakistan relation get tensed.

\section{Social Vulnerability of Social Status}

All the fishermen unanimously say that they cannot buy new clothes for their children, they cannot get examined their children by a doctor because their earning is enough only to run the kitchen. One fisherman miserably said, "Look at our clothes that we are wearing, you can see dust and torn clothes, look at our face, and we looked older than our age. It is just because of poverty; the poverty has been brought by climate change." They are of the view that in the past, economic conditions were better, now they are facing financial crises as sea trip is much more expensive. They do not have savings, becoming unemployed, and are getting under debt while fishing boats are reducing.

One fisherman says that his one son is a worker on another big boat because he makes one trip in the creek, his boat is not big enough to sail in the open sea; its' capacity is limited, he cannot buy a big 
Social Vulnerability of Coastal Community Due to Climate Change

boat because the cost is higher than his financial capacity. Now, fishermen from other areas like of Indus delta area have come there for fishing in creeks. As the water in the Indus delta is reducing day by day, the fishermen of fresh water and the Indus River have switched to sea fishing.

\section{Vulnerability of Fish Production}

Climate change has also affected the species of fish, crabs, and shrimps. Crabs, lobsters, and Prawns are not frequently available near shore.

The fishermen show their concerns about the vulnerability of the production of different types of fish due to climate change. They are of the view that there was a black and white shark that was 4-5 feet long, but now it is not found in the sea. Moreover, halda fish, white and black populate, and danger are shrinking in numbers as well. Similarly, the availability of blue, red, and white snappers is also affected due to climate change. Kalari, patas, short, and tiger were types of shrimp, but now very few are found. Most of these fishes are now in the open and deep sea. A fisherman has to sail a lot to catch these fish, and sailing to open and deep-sea requires a lot of expenditure and a big boat. In addition to it, climate change has also affected quality of fish. The low-quality fish also adds to the social vulnerability of fishermen.

\section{Vulnerability of Health}

As fishermen are going in open sea and their stay in the sea increased, reciprocally, it deteriorates their health. Their faces are rubbed with a strong wind that carries salt and water vapours. Their life expectancy is also affected. To earn more, they try to sell all fish and keep some pieces for their family members. In this way, their women and children become undernourished. Similarly, the growth of their children is also affected. Due to poverty, they can't call to doctor for medical check-ups of their women and children. They even do not visit the medical petitioner. One reason is that health facilities are not available in nearby areas. Another reason is that they cannot afford medical expenditures like tests, fees, etc. Fishermen are also facing eyesight and skin allergy problem. They also take gutka (a kind of tobacco) to keep busy when they are in open sea. Now they have become habitual of it, either are at home or in sea, they routinely take gutka, which increases the risk of mouth cancer.

\section{Middlemen role, Illegal and Detrimental Practices of Fishing Techniques}

Other than climate changes, the contract system and middlemen's role have also exploited fishermen very badly. The Chinese and Japanese fishing trolleys have also affected the fishing of local fishermen. This is because the local fishermen have traditional and local types of boats that are not equipped with the latest technology to catch fish and preserve it.

With the increase in poverty of local fishermen, much more investments have been seen in marine fishing. To fill the gaps, big investors started buying new big boats that can sail in open sea and can stay there for many days. Now, most of the fishing boats are owned by seths (investors). Moreover, the local fishermen of Thatta, Sujwal, and the Badin coastal region have not any proper access to the market. Due to the long distance of Karachi and little orientation and information about the Karachi market, they are bound to sell their fish in the local market and to middlemen. The middlemen buy the fish at a very low rate. Moreover, the middlemen provide loans and finance for repairing boats and family expenditures, which kept poor fishermen under debt. It is not easy to pay loans and the fishermen cannot move out from this circle. The labourers of big boats are forced to use bola and rush nets for fishing that are harmful to fish species. According to the fishermen, the fishery department is neither effective nor efficient to control the rates of fish.

In the past, fishing practices were very simple and environment friendly. But now, because of the involvement of greedy seths, fishing practices are very dangerous to fish and other fauna. Fishermen record their resentments that the techniques and type of nets being used are very dangerous for fish growth and production; goli, Rangan and pori types of fish production is getting low day by day.

The current study reveals that the fishermen, who have a better socio-economic background, their social vulnerability is comparatively less than those who have a lower socioeconomic background. For 
Iqbal \& Abro

example, fishermen with two three to two boats can earn more than those who have one boat or work at someone else boats. Similarly, fishermen who have more male adult family members are less vulnerable than those who have a few male family members. One fisherman says that he has four sons and they all work in the boats, and they are economically comfortable. Another fisherman says that he has two sons but only one son can go for fishing as his second son is not old enough to go for fishing. The results of the study are consistent with Burton, et al (2018) and Mohapatra and Upadhyaya (2020) who are of the view that socioeconomic conditions reduce the social vulnerability of the coastal community.

Moreover, in this study, approximately, all fishermen are illiterate and are uneducated. So they do not know new techniques and equipment of fishing and packages, have little information and market access, which is why they feel comfortable selling their catch (fish) to the middleman. As the income of fishermen is low and they live from hand to mouth, their social status is not good. Similarly, Guths, et a, (2017) are of the view that the lower social status increases social vulnerability due to natural disasters. Most fishermen live in the remote coastal areas and are far away from the cities like Thatta, Garo, Badin, Golarchi, Sujwal. In this way their physical and social world is secluded. This issue is also pointed out by Mavhura et al., (2017).

\section{CONCLUSION}

The study has found that fishermen of the coastal region of Sindh demonstrate social vulnerability. The study reveals that climate change has marginalized the fishermen in the coastal region. The livelihood, health and socio economic status of the fishermen has suffered a lot due to climate change. The study has discovered that climate change has deteriorated their health because of increased duration of their sea trips. In addition to it, an increase in expenditure of fish catch and availability of low quality fish has curtailed their incomes and savings. The study has also revealed that for fishermen (who have been in fishing since ages), it is not easy to go in open and deep sea for fishing. For such kind of trips, a wellequipped boat along with lots of financial resources is required. It has been noticed that about forty to fifty year ago, the fishermen had substantial earnings and saving because they used to find fish near shore where fish were in abundance and easily found, but now due to climate change, sailing in the open sea is restricted by the capacity of their boats. The middlemen and seth (investors) have developed inequalities among fishermen. It means that climate change has reduced the resources of their livelihood and lowered their social status. There is much increase in social vulnerability of coastal community due to climate change that has contributed in enhancing inequality, sense of insecurity, and uncertainty among fishing community of the coastal region of Sindh.

\section{RECOMMENDATION}

As the health of fishermen is concerned, there must be a comprehensive study to find out their health issues in details. Moreover, the study suggests to identify the role of seth in lowering socioeconomic status of fishermen. The study also suggests to explore the issues of children and the women in the area.

\section{REFERENCE}

Adger, W.N. (1999). Social vulnerability to climate change and extremes in coastal Vietnam. World Development, 27(2), 249-269.

Adger, W.N. (2006). Vulnerability. Global Environmental Change, 16(3), 268-281.

Alhassan, S.I., Kuwornu, J.K., \& Osei-Asare, Y.B. (2019). Gender dimension of vulnerability to climate change and variability. International Journal of Climate Change Strategies and Management, 11(2), 195-214.

Arkema, K.K., Guannel, G., Verutes, G., Wood, S.A., Guerry, A., Ruckelshaus, M., \& Silver, J.M. (2013). Coastal habitats shield people and property from sea-level rise and storms. Nature Climate Change, 3(10), 913-918.

Asugeni, J., MacLaren, D., Massey, P.D., \& Speare, R. (2015). Mental health issues from rising sea level 
in a remote coastal region of the Solomon Islands: Current and Future. Australasian Psychiatry, 23(6), 22-25.

Bengtsson, M. (2016). How to plan and perform a qualitative study using content analysis. NursingPlus Open, 2, 1-7.

Berke, P., Yu, S., Malecha, M., \& Cooper, J. (2019). Plans that disrupt development: Equity policies and social vulnerability in six coastal cities. Journal of Planning Education and Research, 00(0), 1-16.

Berman, M., Baztan, J., Kofinas, G., Vanderlinden, J.P., Chouinard, O., Huctin, J.M., \& Thomson, K. (2020). Adaptation to climate change in coastal communities: Findings from seven sites on four continents. Climatic Change, 159(1), 1-16.

Birkmann, J., Cardona, O.D., Carreño, M.L., Barbat, A.H., Pelling, M., Schneiderbauer, S. \& Welle, T. (2013). Framing vulnerability, risk and societal responses: The MOVE framework. Natural hazards, 67(2), 193-211.

Bunce, M., Rosendo, S., \& Brown, K. (2010). Perceptions of climate change, multiple stressors and livelihoods on marginal African coasts. Environment, Development and Sustainability, 12(3), 407440.

Burton, C., Rifai, S., \& Malhi, Y. (2018). Inter-comparison and assessment of gridded climate products over tropical forests during the 2015/2016 El Niño. Philosophical Transactions of the Royal Society B: Biological Sciences, 373(1760).

Cahaya, A., Akib, H., Said, F., \& Yahyaddin, M. (2019). Snapshot of the socio-economic life of fishermen community based on social entrepreneurship in Bone Regency, Indonesia. Academy of Entrepreneurship Journal, 25(1), 1-11.

Chakraborty, L., Rus, H., Henstra, D., Thistlethwaite, J., \& Scott, D. (2020). A place-based socioeconomic status index: Measuring social vulnerability to flood hazards in the context of environmental justice. International Journal of Disaster Risk Reduction, $\mathrm{xxx}$ ( $\mathrm{xxxx}$ ) xxx-xxx.

Chaudhry, Q. U. Z. (2017). Climate change profile of Pakistan. Asian Development Bank.

Clare, L., \& Weninger, B. (2010). Social and biophysical vulnerability of prehistoric societies to rapid climate change. Documenta Praehistorica, 37, 283-292.

Collins, T.W., Grineski, S.E., Ford, P., Aldouri, R., Aguilar, M.D. L.R., Velázquez-Angulo, G., \& Lu, D. (2013). Mapping vulnerability to climate change-related hazards: children at risk in a US-Mexico border metropolis. Population and Environment, 34(3), 313-337.

Collomb, J.D. (2014). The ideology of climate change denial in the United States. European journal of American studies, 9(9-1).

Conner, T.A. (2005). Social vulnerability and adaptive capacity to climate change impacts: Identifying attributes in two remote coastal communities on Haida Gwaii, British Columbia, Masters Thesis. University of Victoria.

Cutter, S. L., Boruff, B. J., \& Shirley, W. L. (2009). Social vulnerability to environmental hazards. Social science quarterly, 84(2), 242-261.

Devers, K.J., \& Frankel, R.M. (2000). Study design in qualitative research--2: Sampling and data collection strategies. Education for health, 13(2), 263-271.

Dolan, A.H., \& Walker, I.J., (2003). Understanding vulnerability of coastal communities to climate change related risks. Journal of Coastal Research, SI 39 (Proceedings of the 8th International Coastal Symposium). Itajaí, SC - Brazil, ISSN 0749-0208.

Drakes, O., Tate, E., Rainey, J., \& Brody, S. (2021). Social vulnerability and short-term disaster assistance in the United States. International Journal of Disaster Risk Reduction, 53, 102010. 
Ekanem, J.T., \& Umoh, I.M. (2021). Social vulnerability of rural dwellers to climate variability: Akwa Ibom State, Nigeria. In African Handbook of Climate Change Adaptation, 2269-2291.

Elliott, R. (2018). The sociology of climate change as a sociology of loss. European Journal of Sociology/Archives Européennes de Sociologie, 59(3), 301-337.

Elrick, B.C.E., Smith, T.F., Thomsen, D.C., \& Preston, B.L. (2015). Perceptions of risk among households in two Australian coastal communities. Geographical Research, 53(2), 145-159.

Farooqi, A.B., Khan, A.H., \& Mir, H. (2005). Climate change perspective in Pakistan. Pakistan Journal of Meteorology, 2 (3). 11-21.

Felsenstein, D., \& Lichter, M. (2014). Social and economic vulnerability of coastal communities to sealevel rise and extreme flooding. Natural Hazards, 71(1), 463-491.

Fussel, H. M. (2007). Vulnerability: A generally applicable conceptual framework for climate change research. Global environmental change, 17(2), 155-167.

Glavovic, B.C., \& Boonzaier, S. (2007). Confronting coastal poverty: Building sustainable coastal livelihoods in South Africa. Ocean \& Coastal Management, 50(1-2), 1-23.

Guths, J.F.D.S., Jacob, M.H.V.M., Santos, A.M.P.V.D., Arossi, G.A., \& Béria, J.U. (2017). Socio demographic profile, family aspects, perception of health, functional capacity and depression in institutionalized elderly persons from the north coastal region of Rio Grande do Sul, Brazil. Revista Brasileira de Geriatria e Gerontologia, 20(2), 175-185.

Hunter, L.M. (2006). Household strategies in the face of resource scarcity in coastal Ghana: Are they associated with development priorities? Population Research and Policy Review, 25(2), 157-174.

Jamali, M.B., Shah, S.M.Z., Shah, A.A., Shafique, K., \& Shaikh, F.M. (2011). Impact Analysis of Public Sector and NGO's to Improvement of Rural Livelihoods in Sindh. International Journal of Business and Management, 6(2), 236.

Katic, K. (2017). Social vulnerability assessment tools for climate change and DRR programming, A guide to practitioners, United Nations Development Programme.

Kayani, M.A. (2017). Gender dimensions of climate change in Pakistan: Reducing the vulnerabilities of rural women to climate change effects in the province of Sindh, Doctoral dissertation, Duke University.

Kelly, P.M., \& Adger, W.N. (2000). Theory and practice in assessing vulnerability to climate change and facilitating adaptation. Climatic change, 47(4), 325-352.

Khan, A.R. (2001). Local knowledge and capacity in management of disaster and vulnerability; A Case study of coastal area of Sindh [Doctoral dissertation, University of Sindh, Jamshoro].

Khawaja, W.S., Xinhai, L., \& Muhammad, R. (2014). Issues and challenges in inter-organizations' disaster management in underdeveloped coastal areas of Pakistan. International Journal of Academic Research in Business and Social Sciences, 4(5), 140.

Khushk, A.M., \& Lashari, M.I. (2007). Issues and options in the production of high value crops in coastal region of Pakistan. Bangladesh Journal of Agricultural Research, 32(3), 359-368.

Kulkarni, M.M., Varun, N., Rathi, P., Eshwari, K., Ashok, K., \& Kamath, V.G. (2016). Health status of school children in rural area of coastal Karnataka. Medical Journal of Dr. DY Patil University, 9(1), 31.

Lockie, S. (2015). What is environmental sociology? Environmental Sociology, 1(3), 139-142.

Lu, D. (2013). Mapping vulnerability to climate change-related hazards: Children at risk in a US-Mexico border metropolis. Population and Environment, 34(3), 313-337.

Mahessar, A.A., Qureshi, A.L., Siming, I.A., Kori, S.M., Dars, G.H., Channa, M., \& Laghari, A.N. 
(2019). Flash flood climatology in the lower region of Southern Sindh. Engineering, Technology \&Amp; Applied Science Research, 9(4), 4474-4479. https://doi.org/10.48084/etasr.2726

Martins, I.M., \& Gasalla, M.A. (2020). Adaptive capacity level shapes social vulnerability to climate change of fishing communities in the South Brazil Bight. Frontiers in Marine Science, 7.

Mayfield-Johnson, S., Fastring, D., Le, D., \& Nguyen, J. (2020). Addressing the social vulnerability of Mississippi Gulf Coast Vietnamese Community through the Development of Community Health Advisors. Sustainability, 12(9), 3892.

Mavhura, E., Manyena, B., \& Collins, A. E. (2017). An approach for measuring social vulnerability in context: The case of flood hazards in Muzarabani district, Zimbabwe. Geoforum, 86, 103-117.

McCarthy, J. J., Canziani, O. F., Leary, N. A., Dokken, D. J., \& White, K. S. (Eds.). (2001). Climate

change 2001: impacts, adaptation, and vulnerability: contribution of Working Group II to the third assessment report of the Intergovernmental Panel on Climate Change (Vol. 2). Cambridge University Press.

Meyappan, M., Loh, W.S.A., Tan, L.Y., Tan, S.F.I., Ho, P.Y., Poh, Y.J., \& Tan, N.C. (2021). Development of a novel gout treatment patient decision aid by patient and physician: A qualitative research study. Health Expectations, 24(2), 431-443.

Mohapatra, S., \& Upadhyaya, A. (2020). Unit-3 Social vulnerability. Indira Gandhi National Open University, New Delhi.

Nawaz, J., \& Naeem, G. (2016). Coastal hazard early warning systems in Pakistan: Tsunami and Cyclone early warning dissemination: Gaps and capacities in Coastal Areas of Balochistan and Sindh Provinces, OXFAM Research Reports

Nicholls, R.J., Wong, P.P., Burkett, V., Woodroffe, C.D., Hay, J. (2008). Climate change and coastal vulnerability assessment: Scenarios for integrated assessment. Sustainability Science, 3(1), 89-102.

Oliver-Smith, A. (2009). Sea level rise and the vulnerability of coastal peoples: Responding to the local challenges of global climate change in the 21st century. Institute for Environment and Human Security, United Nation University.

Omerkhil, N., Chand, T., Valente, D., Alatalo, J.M., \& Pandey, R. (2020). Climate change vulnerability and adaptation strategies for smallholder farmers in Yangi Qala District, Takhar, Afghanistan. Ecological Indicators, 110, 105863.

Pakistan, M. F. F. (2016). A handbook on Pakistan's coastal and marine resources. MFF Pakistan, Pakistan.

Pallewatta, N. (2010). Impacts of climate change on coastal ecosystems in the Indian Ocean region. Coastal Zones and Climate Change, New York: The Henry L. Stimson Center, 3-16.

Qureshi, M.T. (2011). Integrated Coastal Zone Management Plan for Pakistan, IUCN(International Union for Conservation of Nature.

Rasul, G., Ahmad, B, Zahid, M., \& Bukhari. A.A.S. (2012). Climate change in Pakistan. Pakistan Meteorological Department

Razzaq, K.A., Ahmed, P.D.P., Abdida, T.D., \& Razzaq, K.S. (2012). Capacity of local communities in pre and post disasters situation in coastal area of Pakistan, MPRA Paper No. 37076

Salik, K.M., Jahangir, S., \& ul Hasson, S. (2015). Climate change vulnerability and adaptation options for the coastal communities of Pakistan. Ocean \& Coastal Management, 112, 61-73.

Samarakoon, J. (2004). Issues of livelihood, sustainable development, and governance: Bay of Bengal. AMBIO: A Journal of the Human Environment, 33(1), 34-44. 
Shameem, M.I.M., Momtaz, S., \& Rauscher, R. (2014). Vulnerability of rural livelihoods to multiple stressors: A case study from the southwest coastal region of Bangladesh. Ocean \& Coastal Management, 102, 79-87.

Singh, S.R., Eghdami, M.R., \& Singh, S. (2014). The concept of social vulnerability: A review from disasters perspectives. International Journal of Interdisciplinary and Multidisciplinary Studies, 1(6), 71-82.

Sultana, F. (2010). Living in hazardous water scapes: Gendered vulnerabilities and experiences of floods and disasters. Environmental Hazards, 9(1), 43-53.

Torresan, S., Critto, A., Rizzi, J., \& Marcomini, A. (2012). Assessment of coastal vulnerability to climate change hazards at the regional scale: the case study of the North Adriatic Sea. Natural Hazards and Earth System Sciences, 12(7), 2347-2368.

Turner, D.W. (2010). Qualitative interview design: A practical guide for novice investigators. The Qualitative Report, 15(3), 754-760

Uddin, M.N., Islam, A.S., Bala, S.K., Islam, G.T., Adhikary, S., Saha, D., \& Akter, R. (2019). Mapping of climate vulnerability of the coastal region of Bangladesh using principal component analysis. Applied geography, 102, 47-57.

Ullah, Z., Khan, J., \& Haq, Z.U. (2018). Coastal Tourism \& CPEC: Opportunities and Challenges in Pakistan. Journal of Political Studies, 25(2), 261-272

Waly, N.M., Ayad, H.M., \& Saadallah, D.M. (2021). Assessment of spatiotemporal patterns of social vulnerability: A tool to resilient urban development Alexandria, Egypt. Ain Shams Engineering Journal, 12(1), 1059-1072. 